\title{
Analysis of Major Air Pollutants and Submicron Particles in New York City and Long Island
}

M. Masiol, ${ }^{1}$ P. K. Hopke, ${ }^{1}$ H.D. Felton, ${ }^{2}$ B.P. Frank, ${ }^{2}$ and O.V. Rattigan ${ }^{2}$, M.J. Wurth ${ }^{2}$, and G.H. LaDuke $^{2}$

${ }^{1}$ Center for Air Resources Engineering and Science, Clarkson University, Potsdam, NY 13699, United States

${ }^{2}$ NYS Department of Environmental Conservation, Division of Air Resources, BAQS, Albany NY 12233-3256, United States

\begin{abstract}
A year-long sampling campaign of major air pollutants and submicron particle number size distributions was conducted at two sites taken as representative of city-wide air quality in New York City and Long Island, respectively. A number of species were quantified with hourly time resolution, including particle number concentrations in 6 size ranges $(20-30 \mathrm{~nm}, 30-50 \mathrm{~nm}, 50-70$ $\mathrm{nm}, 70-100 \mathrm{~nm}, 100-200 \mathrm{~nm}$, and >200 nm), nitrogen oxides, sulfur dioxide, ozone, carbon monoxide, methane, non-methane hydrocarbons, $\mathrm{PM}_{2.5}$ mass concentration and some PM major components (sulfate, organic and elemental carbon). Hourly concentrations of primary and secondary organic carbon were estimated using the EC tracer method. Data were matched with weather parameters and air parcel back-trajectories. A series of tools were thus applied to: (i) study the seasonal, weekly, diurnal cycles of pollutants; (ii) investigate the relationships amongst pollutants through correlation and lagged correlation analyses; (iii) depict the role of atmospheric photochemical processes; (iv) examine the location of the potential sources by mean of conditional bivariate probability function analysis and (v) investigate the role of regional transport of air masses to the concentrations of analyzed species. Results indicate that concentrations of $\mathrm{NO}_{\mathrm{x}}, \mathrm{SO}_{2}, \mathrm{CO}$, non-methane hydrocarbons, primary $\mathrm{OC}$ and $\mathrm{EC}$ are predominantly determined by local sources, but are also affected by regional transports of polluted air masses. On the contrary, the transport of continental polluted air masses has a main effect in raising the concentrations of secondary $\mathrm{PM}_{2.5}$ (sulfate and secondary organic carbon). By providing direct information on the concentrations and trends of key pollutants and submicron particle number concentrations, this study finally enables some general considerations about air quality status and atmospheric processes over the New York City metropolitan area.
\end{abstract}

Keywords: Air quality; New York City, Nitrogen oxides; Organic carbon; Sulfate; Particle size. 


\section{INTRODUCTION}

Over the last several decades, an increasing number of epidemiologic studies have concluded that ambient air pollution and particularly airborne particulate matter (PM) are causal risk factors for many adverse human health effects, including respiratory illnesses (Götschi et al., 2008; Laumbach and Kipen, 2012; Adam et al., 2015), cardiovascular diseases (Anderson et al., 2012; Shah et al., 2013; Franklin et al., 2015) and carcinogenic effects (Turner et al., 2011; Pope et al., 2011; Loomis et al., 2013). Given the biological evidence, outdoor air pollution and airborne particulate matter (PM) have been categorized in class 1 by the International Agency for Research on Cancer in 2013, i.e. known carcinogenic to human beings (Straif et al., 2013).

A significant drop in the ambient concentrations of many air pollutants has been measured in many developed countries (including U.S.) as a result of implementation of legislation and regulations through the application of successful abatement technologies and other mitigation measures (Parrish et al., 2011; Colette et al, 2011). Current United States air quality is regulated through the National Ambient Air Quality Standards (NAAQS) that set limit values to be attained across U.S. for pollutants considered harmful to public health and the environment, i.e. nitrogen dioxide $\left(\mathrm{NO}_{2}\right)$, ozone $\left(\mathrm{O}_{3}\right)$, sulfur dioxide $\left(\mathrm{SO}_{2}\right)$, carbon monoxide (CO), PM with aerodynamic diameters less than 10 and $2.5 \mu \mathrm{m}\left(\mathrm{PM}_{10}\right.$ and $\mathrm{PM}_{2.5}$, respectively) and particle-bound lead.

New York City (NYC) is the most populous city in the U.S. with $\sim 8.5$ million inhabitants in 2014. However, the population reaches almost 20 million inhabitants when considering the whole New York-New Jersey-Pennsylvania metropolitan area. Air quality has generally improved since 1970s across NYC (NYC Department of Health and Mental Hygiene, 2013a). For example, Parrish et al. (2011) have reported slow improvements for both ozone and $\mathrm{PM}_{2.5}$ between 2000 and 2010, while Duncan et al. (2016) have observed a strong decrease (-45.5\%) in $\mathrm{NO}_{2}$ from 2005 to 2014. Downward trends in air pollutants across New York were observed by Buckley and Mitchell (2011), while substantial decreases in $\mathrm{PM}_{2.5}$ mass and major components across New York since the early 2000s were reported by Rattigan et al. (2016). Currently, NAAQS are generally not exceeded in NYC (NY State Dep. Environmental Conservation, 2016), except for ozone (marginal to moderate non-attainment). However, air pollution still remains a serious concern for policy-makers and the scientific community in NYC as well as in 
the whole metropolitan area. Even with attainment of the NAAQS, it has been estimated that ambient concentrations of $\mathrm{PM}_{2.5}$ in NYC still contribute to more than 3000 deaths every year, 2000 hospital admissions for lung and heart conditions, and approximately 6000 emergency department visits for asthma in children and adults (NYC Department of Health and Mental Hygiene, 2013a;b).

Despite the number of stations measuring air quality and the large number of scientific studies available in literature, limited data are still available for some air pollutants, including submicron particles (SMPs, $<1 \mu \mathrm{m}$ ) and ultrafine particles (UFPs, less than $100 \mathrm{~nm}$ in diameter), which have been widely associated with severe adverse effects upon human health (e.g., Knibbs et al., 2011; Strak et al., 2012; Ostro et al., 2015; Lanzinger et al., 2016). Moreover, limited studies have focused on air pollution climate, i.e. on the relationships amongst air pollution and weather.

This study investigates air pollutions in NYC and Long Island through the analysis of hourly-resolved concentrations of common gaseous air pollutants, $\mathrm{PM}_{2.5}$ mass and $\mathrm{PM}_{2.5}$-bound major species, submicron particle number concentrations and their size distributions, with special emphasis for UFPs. Intensive sampling campaigns were simultaneously conducted at two sites: Queens (NYC) and Eisenhower Park (Long Island). A large set of air pollutants was measured over 1 year (2009-2010) at $1 \mathrm{~h}$ intervals. Datasets include: (i) key gaseous air pollutants, i.e. nitrogen oxides $\left(\mathrm{NO}+\mathrm{NO}_{2} \equiv \mathrm{NO}_{\mathrm{x}}\right)$, sulfur dioxide $\left(\mathrm{SO}_{2}\right)$, ozone $\left(\mathrm{O}_{3}\right)$, carbon monoxide $(\mathrm{CO})$, methane $\left(\mathrm{CH}_{4}\right)$, non-methane hydrocarbons (NMHCs), total hydrocarbons (THCs); (ii) $\mathrm{PM}_{2.5}$ mass and $\mathrm{PM}_{2.5}$-bound species, such as sulfate $\left(\mathrm{SO}_{4}{ }^{2-}\right)$, organic (OC), elemental (EC) and total (TC) carbon; (iii) particle number concentrations (PNC) over 6 size ranges $(20-30 \mathrm{~nm}, 30-50 \mathrm{~nm}$, $50-70 \mathrm{~nm}-70-100 \mathrm{~nm}, 100-200 \mathrm{~nm}$, and 200 to $\sim 1000 \mathrm{~nm}$ ). The concentrations of primary and secondary organic carbon were estimated using an EC tracer method (Section 3.1). The seasonal, weekly, and diurnal cycles of the air pollutants were investigated in detail along with several derived variables (Sections 4.1 and 4.2). Data were matched with micro-meteorological parameters and analyzed to explore the possible effects of weather upon the air quality and to locate the probable local emission sources (Section 4.4). A back-trajectory-based hybrid model was applied for assessing the potential role of regional and long-range transports upon air quality (Section 4.5). These results give important insights into pollutant sources, influences upon 
concentrations and key inter-relationships in pollutant behaviors and presents a synthesized description of pollution climate regimes for typical urban sites in NYC or even for large cities across northeastern U.S. having similar anthropogenic activities and weather conditions.

\section{MATERIALS AND METHODS}

\subsection{Site description}

Measurements were made from June 2009 to July 2010 at two sites categorized as urban, i.e. representative of city-wide background pollution concentrations. Queens College (QC: $40^{\circ}$ $44.225^{\prime} \mathrm{N} ; 73^{\circ} 49.295^{\prime} \mathrm{W} ; 24 \mathrm{~m}$ a.s.l.) is located in a high population density section of Queens County (Figure 1) and it is representative of the New York City metropolitan area. QC is also affected by emissions from two traffic highways, i.e. the Long Island Expressway (I-495) and the Van Wyck Expressway (I-678). Eisenhower Park (EP: 40 44.586'N 73³5.132'W; 25 m a.s.l.) is situated on the border of a $3.8 \mathrm{~km}^{2}$-wide public park located in Nassau County. The park is devoted to many entertainment and sport activities and is backed by unoccupied parklands. However, EP is also affected by: (i) heavy road traffic as it is adjacent to a 4 lane roadway that runs parallel to the site in a NNW direction, within $22 \mathrm{~m}$ of a roadway in a W-WSW direction, and within $53 \mathrm{~m}$ of the roadway in a $\mathrm{S}$ direction; and (ii) emissions from a waste-to-energy conversion plant and from several restaurants close to the site (Figure 1).

\subsection{Experimental}

Instruments were operated continuously over the sampling period to quantify ambient air pollutant concentrations with $1 \mathrm{~h}$ resolution time. A more extensive range of pollutants were monitored at QC (NO, $\mathrm{NO}_{2}, \mathrm{NO}_{\mathrm{x}}, \mathrm{SO}_{2}, \mathrm{O}_{3}, \mathrm{CO}, \mathrm{CH}_{4}, \mathrm{NMHCs}, \mathrm{THC}, \mathrm{PM}_{2.5}, \mathrm{SO}_{4}{ }^{2-}, \mathrm{OC}, \mathrm{EC}, \mathrm{TC}$ and SMP) than at $\mathrm{EP}\left(\mathrm{NO}, \mathrm{NO}_{2}, \mathrm{NO}_{\mathrm{x}}, \mathrm{SO}_{2}, \mathrm{PM}_{2.5}\right.$ and $\left.\mathrm{SMP}\right)$.

Two ultrafine particle monitors (TSI Model 3031) were deployed at both sites to measure particle size distributions from $20 \mathrm{~nm}$ (electrical mobility diameter) to approximately $\mathrm{PM}_{2.5} \mu \mathrm{m}$ in six channels: $20-30 \mathrm{~nm}$ (ch1), 30-50 nm (ch2), 50-70 nm (ch3), 70-100 nm (ch4), 100-200 nm (ch5) and >200 nm (ch6). The instruments operated with $\mathrm{PM}_{2.5}$ cyclones, i.e. the upper size was set to particles with an aerodynamic diameter less than $2.5 \mu \mathrm{m}$. The operating 
principle of the UFP monitor is based diffusion charging of particles using a "Corona-Jet" charger (Medved et al., 2000), followed by size segregation in a differential mobility analyzer and detection via a sensitive electrometer.

U.S. EPA equivalent or reference methods were used for the gas measurements (Thermo Electron Corporation model 42C NO- $\mathrm{NO}_{2}-\mathrm{NO}_{x}$; model 43C SO 2 ; model 49C O 3 ; model $48 \mathrm{C} \mathrm{CO}$ ). Methane, Non-Methane Hydrocarbons (NMHCs), and total hydrocarbons (THC) were analyzed using flame ionization detector method (model APHA-360, HORIBA Ltd., Japan).

$\mathrm{PM}_{2.5}$ mass concentrations were measured with tapered element oscillating microbalances (Thermo-Fisher Scientific TEOM 1400ab) with $2.5 \mu \mathrm{m}$ cut size inlets. However, a TEOM-FDMS system was deployed at QC, while a simple TEOM was used at EP. The main concern with the use of the simple TEOM technique is the loss of the more volatile component (principally some semi-volatile hydrocarbons and nitrates) because the inlet is held at a temperature $\sim 50^{\circ} \mathrm{C}$. A non-linear Julian Day based adjustment was thus applied to the TEOM data: it removes much of the seasonal bias and gives approximate comparability with the Federal Reference Method (FRM). Details are reported by Felton (2005) and Schwab et al. (2006).

Particulate sulfate was determined with a sulfate analyzer (Thermo Scientific model 5020i), while particulate carbonaceous components (OC, EC, TC) were quantified by a semicontinuous carbon aerosol analyzer (Sunset Lab., Tigard, OR, USA) operating a modified NIOSH 5040 thermo-optical protocol on an hourly sample collection similar to Bauer et al. (2009). For EC, both the thermal (EC) and "black" optical EC (opt. EC at $632 \mathrm{~nm}$ ) were quantified.

\subsection{Weather data and meteorology-based models}

Ambient air temperature, wind speed and direction, relative humidity $(\mathrm{RH})$ and atmospheric pressure were recorded hourly at weather stations which were chosen as representative of the average weather conditions across the study area: LaGuardia and Republic airports, respectively, for QC and EP. Since no direct solar radiation (SR) data were available at the weather stations, the total direct and diffuse SR (METSTAT-modeled) was retrieved from the National Solar Radiation Database (NREL, 2012).

Conditional probability function (CPF) analysis is widely used to locate the potential local sources affecting a site. It is performed by matching wind direction data with air pollutants 
concentrations (Kim et al., 2003; Pekney et al., 2006; Kara et al., 2015). More recently, this approach was extended to the bivariate case to produce a conditional bivariate probability function $(\mathrm{CBPF})$ plots using wind speed as a third variable plotted on the radial axis. It is defined as:

$C_{B P F_{\Delta \theta, \Delta u}}=\frac{m_{\Delta \theta, \Delta u} \mid C \geq x}{n_{\Delta \theta, \Delta u}}$

where $\mathrm{m}_{\Delta \theta, \Delta \mathrm{u}}$ is the number of samples in the wind sector $\Delta \theta$ with wind speed interval $\Delta u$ having concentration $C$ greater than the threshold value $x$ (concentrations $>75$ th percentile, in this case), $n_{\Delta \theta, \Delta u}$ is the total number of samples in that wind direction-speed interval: details of the method are provided in Uria-Tellaetxe and Carslaw (2014). CBPF assesses the probability that a source contribution from a given wind direction/speed sector exceeds the 75 th percentile of a pollutant. This approach was used to identify the most probable local emission sources.

Back-trajectories were computed by the NOAA/ARL hybrid single particle Lagrangian integrated trajectory (HYSPLIT4) model (Stein et al., 2015; Rolph, 2016) from the NCEP/NCAR Reanalysis data. The HYSPLIT parameters were set as $-96 \mathrm{~h}$ run time with a starting height of $500 \mathrm{~m}$ a.g.l. The potential source contribution function (PSCF) (Ashbaugh et al., 1985; Lee and Hopke, 2006; Hopke, 2016) was used to identify regional scale source locations. PSCF calculates the conditional probability that a source is located at latitude $i$ and longitude $j$ as:

$P S C F=\frac{m_{i, j}}{n_{i, j}}$

where $n_{i, j}$ is the number of times the trajectory endpoints fell into the $i, j$-th cell in the domain grid, and $m_{i, j}$ represents the number of times the concentrations exceed a threshold (concentrations $>75$ th percentile, in this case). The cells with high PSCF probabilities indicate a likely source location. Since cells with few data may bias the results, a weighting factor is applied to reduce their effect. The details are provided in Polissar et al. (2001).

Data were analyzed using R version 3.2.2 (R Development Core Team, 2008) and a series of packages including 'openair' (Carslaw and Ropkins, 2012). Details of polar plot analysis shown in this study are given in Carslaw et al. (2006) and Uria-Tellaetxe and Carslaw (2014). 


\section{RESULTS}

Annual concentrations of measured pollutants at the two sites (all available data recorded during the whole study period) are given as box and whisker plots (Figure 2). On average, results show that gaseous species measured at both sites have similar concentrations, following the order (in ppb) $\mathrm{NO}_{\mathrm{x}}\left(28.9\right.$ and $24.5 \mathrm{in} \mathrm{QC}$ and $\mathrm{EP}$, respectively) $>\mathrm{NO}_{2}(19.6,14.3)>\mathrm{NO}(9.4,10.3)>\mathrm{SO}_{2}$ $(2.8,2.3)$. Average $\mathrm{PM}_{2.5}$ mass concentrations were 10 and $9.4 \mu \mathrm{g} \mathrm{m}^{-3}$ at QC and EP, respectively, while total SMPs averaged 8209 and 7596 particles $\mathrm{cm}^{-3}$. The size distributions show the highest concentrations in the 30-50 nm range at both sites, followed by 20-30 nm. Particles >200 nm had the lowest concentrations. QC experiences higher concentrations for all of the measured air pollutants, except for NO.

At QC, annual $\mathrm{PM}_{2.5}$ mass concentrations are dominated by sulfate $(20.9 \%)$ and OC (20.6\%), with EC accounting for 6.5\%. Assuming the sulfate is fully neutralized by ammonia and a OM/OC ratio in the range of 1.9-2.1, as reported for atmospheric aerosols sampled at the Pittsburgh supersite (Polidori et al., 2008), ammonium sulfate accounts for $\sim 25 \%$ of total $\mathrm{PM}_{2.5}$ mass $\left(2.7 \mu \mathrm{g} \mathrm{m}^{-3}\right)$, while organic matter represents $39-43 \%\left(4-5 \mu \mathrm{g} \mathrm{m}^{-3}\right)$.

Additional variables were calculated and the results are shown in Figure 2. The $\mathrm{NO}_{2} / \mathrm{NO}_{\mathrm{x}}$ ratio indicates the complex photochemistry in the $\mathrm{NO}-\mathrm{NO}_{2}-\mathrm{O}_{3}$ system. $\mathrm{NOx}$ emissions from combustion is primarily $\mathrm{NO}(\sim 90 \%)$ and rapidly reacts with $\mathrm{O}_{3}$ and radicals to form $\mathrm{NO}_{2}$ (Jenkin and Hayman, 2000; Finlayson Pitts and Pitts, 2000; Seinfeld and Pandis, 2006). Annual average $\mathrm{NO}_{2} / \mathrm{NO}_{\mathrm{x}}$ ratios were found around 0.8 (0.82 at QC and 0.77 at EP). Total oxidant concentration $\left(\mathrm{OX}=\mathrm{O}_{3}+\mathrm{NO}_{2}\right)$ was calculated as an indirect estimation of the atmospheric oxidative potential (Kley et al., 1999). At QC, annual average OX concentrations were 43 ppb, of which ozone contributed for $54 \%$ and $\mathrm{NO}_{2}$ for the remaining $46 \%$. The sulfate $/ \mathrm{SO}_{2}$ ratio may give important insights upon the degree of $\mathrm{SO}_{2}$ oxidation and on the consequent speciation of sulfur into the two species (Stockwell and Calvert, 1983; Stockwell, 1994). Sulfate accounts for 30-60\% of monthly average $\mathrm{PM}_{2.5}$ mass in the East U.S. (Hand et al., 2012a;b). The sulfate/ $/ \mathrm{SO}_{2}$ ratio was calculated over the mass concentrations normalized for their sulfur content: i.e. converting $\mathrm{SO}_{2}$ to $\mu \mathrm{g} \mathrm{m}^{-3}$ and dividing the species by the respective molecular weights. Annual average of sulfate/ $\mathrm{SO}_{2}$ ratio at $\mathrm{QC}$ was 0.4 . This value indicates that the atmospheric sulfur is primarily oxidized $\mathrm{S}(\mathrm{IV})$. 


\subsection{Primary and secondary organic carbon}

Primary $\left(\mathrm{OC}_{\mathrm{pri}}\right)$ and secondary $\left(\mathrm{OC}_{\mathrm{sec}}\right)$ organic carbon aerosols are important bulk constituents of $\mathrm{PM}_{2.5}$. Secondary $\mathrm{OC}$ is formed in the atmosphere from the oxidation of volatile organic compounds (VOCs) of both biogenic (e.g., Lane and Pandis, 2007; Brown et al., 2009) and anthropogenic (e.g., Ng et al., 2007; Henze et al., 2008; Donahue et al., 2009) origins. It was estimated that $\mathrm{OC}_{\mathrm{sec}}$ accounts for about $35-77 \%$ of total $\mathrm{OC}$ across the continental U.S. (Yu et al., 2004; Cabada et al., 2004a; Yu et al., 2007; de Gouw et al., 2008). In this study, a widely used EC tracer method is applied to estimate the partitioning between $\mathrm{OC}_{\mathrm{pri}}$ and $\mathrm{OC}_{\mathrm{sec}}$ using hourly resolved OC and EC data collected at QC. Briefly, since EC is a primary pollutant, the adopted empiric method assumes that $\mathrm{OC}_{\mathrm{pri}}$ is dependent from $\mathrm{EC}$ :

$\mathrm{OC}_{\mathrm{pri}}=\mathrm{EC} \cdot\left[\frac{\mathrm{OC}}{\mathrm{EC}}\right]_{\mathrm{pri}}+b$

where $\mathrm{OC} / \mathrm{EC}_{\text {pri }}$ is the ratio for the primary sources affecting the site and $b$ includes the noncombustion contribution to $\mathrm{OC}_{\text {pri }}$ and sampling artifacts (Turpin and Huntzicker, 1995; Strader et al., 1999; Lim and Turpin, 2002; Cabada et al., 2004a). Subsequently, $\mathrm{OC}_{\mathrm{sec}}$ can be finally assessed as:

$\mathrm{OC}_{\mathrm{sec}}=\mathrm{OC}-\mathrm{OC}_{\mathrm{pri}}$

The limitations and the uncertainties associated with EC tracer methods have been noted (e.g., Day et al., 2015) and are mainly related to $\mathrm{OC} / \mathrm{EC}_{\text {pri. }}$. This basic method relies on the ability to isolate periods which are dominated by primary EC and OC, i.e. low photochemical secondary organic aerosol (SOA) production. It assumes that primary EC and OC are derived from similar sources and exhibit similar temporal patterns throughout the year. (OC/EC) $)_{\text {pri }}$ is very difficult to measure experimentally and, thus, needs to be estimated. A scatterplot of OC versus EC concentrations for all samples and for samples selected by adopting criteria similarly to Cabada et al. (2004a) is shown in Figure SI1. A clear edge is found at OC/EC=1.07, which is interpreted as the $\mathrm{OC} / \mathrm{EC}_{\text {pri, }}$, whereas no intercept is detected $(b \approx 0)$. Following this procedure, the average concentration of primary $\mathrm{OC}$ was $0.84 \mu \mathrm{g} \mathrm{m}^{-3}$, accounting for $35 \%$ of total $\mathrm{OC}$, while average $\mathrm{OC}_{\mathrm{sec}}$ was $1.55 \mu \mathrm{g} \mathrm{C} \mathrm{m}^{-3}$ (65\%). Similar results were previously observed at a NYC Bronx site (Rattigan et al., 2010). 


\subsection{Inter-site correlations}

Since the Anderson-Darling test for the composite hypothesis of normality applied to the data revealed that variables are generally not normally distributed at $p<0.05$, the nonparametric Kruskal-Wallis ANOVA by ranks was applied to test the significance of differences between the two sites. Results indicate that only $\mathrm{SO}_{2}, \mathrm{PM}_{2.5}$, and $\mathrm{SMP}$ in the range 100-200 nm concentrations were significantly different at $p<0.05$. The correlation coefficients were calculated for the data over the whole sampling campaign (Table SI1) to examine the intersite relationships among pollutants. Results show that many of the variables measured at both sites have moderate to strong correlations ranging from 0.60 for multiple species to 0.78 for $\mathrm{SO}_{2}$ suggesting that one-third to one-half of the variance of analyzed pollutants is the same between the two sites such that there were common pollutant sources contributing at both sites.

\section{DISCUSSION}

\subsection{Seasonal variations}

Seasonal variations for some selected species are shown in Figure 3 that depicts the monthly average concentrations and the associated 95th confidence intervals calculated by bootstrapping the data $(n=200)$, while the seasonal variations for all of the analyzed pollutants are provided in Figure SI2. Nitrogen oxides, $\mathrm{SO}_{2}$, NMHCs, UFPs in the first 3 size increments (20-70 $\mathrm{nm}$ ) show typical seasonal cycles with maxima in the coldest seasons (Nov-Feb) and minima in the warmest months (Jun-Sept). Maxima in winter for such species are due to: (i) increase emissions for building space heating; (ii) the lower mixing layer heights and possibly strong thermal inversions, which limit the dispersion capacity of the atmosphere and trap the local emitted pollutants close to the ground (despite the higher wind speeds in winter), and (iii) the drop of ozone and hydroxyl radical and the consequent lower oxidation potential. The seasonal variation of $\mathrm{NO}$ is more prominent than those of $\mathrm{NO}_{2}$ : the seasonality of $\mathrm{NO}_{2} / \mathrm{NO}_{\mathrm{x}}$ ratio clearly indicates that the partitioning of $\mathrm{NOx}$ is mostly toward $\mathrm{NO}_{2}$ in the warmest season, due to the higher actinic fluxes, higher temperatures, and, the higher atmospheric oxidant concentrations that favors $\mathrm{NO}$ to $\mathrm{NO}_{2}$ oxidation.

Average ozone concentrations show increased values in the warmest periods. OC and sulfate show higher concentrations in the warmest periods (Jul-Aug) along with SMPs in the 
accumulation mode $(>100 \mathrm{~nm})$. Increased concentrations of sulfate in warm seasons are the result of the increase in concentrations of atmospheric oxidants (mainly hydroxyl radical). The pattern is closely related to those of OX, air temperature and RH (Figure 3) as well as expected higher summer ammonia concentrations (Paulot et al., 2014). The sulfate/ $\mathrm{SO}_{2}$ ratios describes the increased speciation toward sulfate in summer: sulfate/ $\mathrm{SO}_{2}$ ratio range from values below 0.3 in winter to $0.8-1$ from May to July.

The pattern of OC is strongly related to the formation of SOA, as evidenced by the comparison with the estimated $\mathrm{OC}_{\mathrm{sec}}$. Alternatively, $\mathrm{OC}_{\mathrm{pri}}$ is more constant through the year, ranging from 0.7 to $1.1 \mu \mathrm{gC} \mathrm{m}^{-3}$. In winter (December-February), $\mathrm{OC}_{\mathrm{sec}}$ account for about $52 \%$ of total OC. In summer (June-August), $\mathrm{OC}_{\mathrm{sec}}$ accounts for $\sim 69-80 \%$ of total OC. This result is comparable with Yu et al. (2004) for the Northeast U.S. $(77 \pm 3 \%)$. These results are also consistent with secondary OC accounting for 40-50\% of total OC during winter and 63-73\% during summer at a NYC Bronx site (Rattigan et al., 2010). The pattern of $\mathrm{OC}_{\mathrm{sec}}$ also well matches with the seasonal variations of SOA predicted by global atmospheric chemical transport models for U.S. (e.g., Liao et al., 2007). de Gouw et al. (2008) reported that organic matter in NE U.S. during summer is mostly the result of formation from anthropogenic VOCs precursors in urban plumes. The warmer seasons also experience increases in the emissions of biogenic VOCs from plants, mostly isoprene and terpenes, which are known strong SOA precursors (Carlton et al., 2009).

Particles in the 100-1000 nm range may originate from a variety of sources. Their seasonality is very similar to sulfate and, thus, may be also the result of secondary processes. This hypothesis is also partially supported by the data on the size resolved chemical composition of PM in northeastern U.S. For example, Cabada et al. (2004b) and Zhang et al. (2005) reported that sulfate is mostly distributed in the 100-1000 nm range at the Pittsburgh supersite.

$\mathrm{CO}$ and methane that along with THC (methane accounts for most of THC mass) show different behaviors. No methane data are available for May and June due to equipment problems. In the U.S., up-dated emission inventories (Miller et al., 2013; US EPA, 2015) report that enteric fermentation is the largest anthropogenic source of methane ( $26 \%$ of total emissions) followed by natural gas system and landfills. Methane showed higher concentrations in April probably the result of increased release from soil and wetlands as the ground warms. Carbon monoxide is primarily emitted by anthropogenic combustion (e.g., vehicular exhaust, domestic heating, 
industrial emissions, and biomass burning). It is also formed by oxidation of methane and NMHCs (Seinfeld and Pandis, 2006). The increases in winter can be primarily linked to space heating emissions and lower atmospheric dispersion similar to $\mathrm{NO}_{\mathrm{x}}, \mathrm{SO}_{2}$ and $\mathrm{NMHCs}$, while the peak in April-May may result from the oxidation of methane.

The remaining pollutants lacked significant seasonal cycles or their patterns were extremely variable. $\mathrm{PM}_{2.5}$ mass concentration showed slightly different patterns at QC and EP. $\mathrm{PM}_{2.5}$ mass concentration in QC exhibits a pattern comparable to sulfate, $\mathrm{OC}_{\mathrm{sec}}$, and particles $>100 \mathrm{~nm}$, consistent with significant secondary processes. However, $\mathrm{PM}_{2.5}$ lacked observable seasonality at EP. This discrepancy is due to the use of different methods. Although the adjustment method applied to TEOM concentrations at EP is able to approximate the data to FRM, it should be noted that FRM does not capture the summer volatile PM. On the contrary, the FDMS system at QC collects more of the semi-volatile material, particularly in summer.

\subsection{Weekly and daily cycles}

Daily cycles (Figure 4 and Figure SI3) and weekly patterns (Figure SI4) are also the result of the interplay among emission strengths, photochemical processes, and micrometeorological factors. The daily cycles were computed after shifting the time to daylight saving time (DST) since sources like traffic and cooking will shift by an hour at the transition from standard to daylight savings and the reverse. Separating the data into two periods produces better-defined diurnal profiles. Generally, most of the analyzed species $\left(\mathrm{NO}, \mathrm{NO}_{2}, \mathrm{NO}_{\mathrm{x}}, \mathrm{SO}_{2}\right.$, CO, HMHCs, $\mathrm{PM}_{2.5}$, sulfate, EC (both thermal and optical) and particles in the 20-200 nm ranges) show daily peaks corresponding to the rush hours of road traffic (6-9 am) and higher concentrations during weekdays. However, only some species $\left(\mathrm{NO}_{2}, \mathrm{SO}_{2}, \mathrm{PM}_{2.5}\right.$, and particles in the 30-200 nm range) also exhibit a second typical mode related to the evening rush hours (6-11 pm). For these latter species, morning and evening maxima are interspersed by lower concentrations that are assumed to be the result of: (i) lower emissions (less traffic); (ii) larger availability of atmospheric oxidants and (iii) higher mixing layer height and wind speeds and, consequently, enhanced atmospheric dispersion.

Ozone behaves oppositely since it depends on photochemical production during the day. Ozone exhibits higher concentrations on weekends as a result of lower emissions of NO typically because of lower heavy duty diesel traffic. The "weekend" effect is common in many airsheds 
(e.g., Pires et al., 2012; Huryn and Gough, 2014). The daily and weekly variations in ozone and anthropogenic emissions give rise to $\mathrm{NO}_{2} / \mathrm{NO}_{\mathrm{x}}$ ratios that show nitrogen oxide partitioning is shifted significantly toward NO during the morning rush hours. Patterns in the sulfate/ $\mathrm{SO}_{2}$ ratios show that: (i) $\mathrm{SO}_{2}$ is always the prevailing sulfur species; and (ii) maxima occur in the afternoon possibly due to the rapid oxidation of $\mathrm{SO}_{2}$ to sulfate enhanced by higher concentrations of oxidants at this time. The only likely local source of sulfate would be the marine diesels (Kim and Hopke, 2008) operating around the Port of Elizabeth.

Total organic carbon in $\mathrm{PM}_{2.5}$ does not show daily cycles, but it does have a strong weekly pattern with minima from Thursdays to Saturdays. Estimated primary and secondary OC show peculiar cycles: $\mathrm{OC}_{\text {pri }}$ has patterns similar to other primary pollutants, such as $\mathrm{NO}$ and $\mathrm{CO}$, i.e. highest concentrations during weekdays and in the morning rush hours; $\mathrm{OC}_{\mathrm{sec}}$ presents maxima during weekends and two peaks of high concentrations during the day. The first peak is in the afternoon correlated to the maximum solar irradiation and, thus, maximum concentrations of atmospheric oxidants (OX). The second peak occurs in the evening and overnight. This could indicate transport of secondary material from other locations (Strader et al., 1999) or enhanced condensation of semi-volatile OC material due to lower ambient temperatures. It can also be hypothesized that the oxidation of VOCs of anthropogenic and natural origins based on nitrate radical oxidation can drive this behavior.

The daily pattern of methane has the inverse pattern of the air temperature. This result suggests that the methane is emitted at ground level and mixing layer dynamics drive its ground level concentrations.

\subsection{Intra-site correlations and cross-correlations}

Intra-site relationships among different analyzed pollutants were investigated through the correlation coefficients. Results are provided as Figures SI5 and SI6 for QC and EP, respectively. Correlation matrices were also clustered by using hierarchical cluster analysis to group pollutants showing similar correlations and help the interpretation of results.

At QC and EP, most variable pairs show moderate to strong correlations. At QC, the cluster analysis reveals that correlations may be split into 3 main groups. The first group links positive correlation among particles in the smaller ranges $(20-100 \mathrm{~nm}$ ) with pollutants directly emitted by combustion sources in urban environments ( $\mathrm{NO}, \mathrm{SO}_{2}, \mathrm{CO}, \mathrm{NMHCs}$ and $\mathrm{EC}$ (both 
thermal and optical EC)), methane and $\mathrm{NO}_{2}$. The presence of cumulative variables $\left(\mathrm{NO}_{\mathrm{x}}\right.$ and THC) is not surprising since $\mathrm{NO}_{2}$ accounts for most (68\%) of $\mathrm{NO}_{\mathrm{x}}$ and methane for most (92\%) of THC. The second cluster shows positive correlations among coarser SMPs (>100 nm), $\mathrm{PM}_{2.5}$ mass concentration, and the main particulate species (OC and sulfate). Since sulfate is a main constituent of $\mathrm{PM}_{2.5}$ mass and $\mathrm{OC}_{\mathrm{sec}}$ accounted for most of the $\mathrm{OC}$ mass, this cluster is likely the result of the secondary aerosol contributions to the $\mathrm{PM}_{2.5}$ mass concentrations. The presence of particles $>100 \mathrm{~nm}$ along with OC and sulfate support their assignment to being secondary accumulation mode PM.

The last group consists only of ozone, and shows negative correlations with all other pollutants. Ozone plays a key role in reacting with primary pollutants and in the generation of secondary aerosol. However, ozone has weak correlations with variables in clusters 1 and 2 . Thus, it can be hypothesized that ozone is driven primarily by local pollutants and chemistry, while sulfate and $\mathrm{OC}_{\mathrm{sec}} \mathrm{PM}$ have a non-local origin. This hypothesis will be investigated further using back-trajectory models.

The cross-correlation functions (CCF) were computed at $\pm 12 \mathrm{~h}$ lag to investigate the relationships among the pollutants and between pollutants and weather parameters in more detail. CCFs are calculated separately for the cold and warm seasons based on local daylight saving time (EST= standard time (Nov 12009 - Mar 14, 2010) and EDT= Eastern daylight time). The most important CCFs for QC and EP are presented in Figures SI7.

Generally, CCFs for pairs of variables shared by the two sites have similar profiles. CCFs for pairs of species mainly emitted by primary emission sources $\left(\mathrm{NO}, \mathrm{CO}, \mathrm{SO}_{2}, \mathrm{NMHCs}\right.$, $\mathrm{OC}_{\mathrm{pri}}, \mathrm{EC}$ ) are characterized by significant strong (>0.6) positive correlations near the $0 \mathrm{~h}$ lag, meaning that they have concurrent daily cycles, i.e. they are potentially emitted by the same set of sources and undergo to similar atmospheric processes. The correlations rapidly decrease by moving lags forward and backward, indicating that the relationships among primary pollutants is quite immediate.

The ozone-solar radiation relationship was used to investigate the photochemical production of ozone. It exhibited a peak at +2 and $+3 \mathrm{~h}$ lags, i.e. the maximal ozone concentrations are delayed relative to the SR maxima. The oxidative chain driven by ozone were further analyzed in terms of the $\mathrm{NO}_{2}-\mathrm{O}_{3}$ and $\mathrm{NO}_{2}-\mathrm{NO}$ pairs. Strong correlations (negative and positive, respectively) occur at lag 0 and reflect the fast kinetics of NO oxidation by ozone and 
hydroxyl radical (Finlayson Pitts and Pitts, 2000). The CCFs for the methane-ozone and sulfateozone pairs show weak correlations $(0.3<\mathrm{r}<0.6)$ over all lag values. Although the correlations are weak, the CCF for sulfate-ozone has positive values during the warm season and negative in cold periods reflecting the temperature dependence of the kinetics of S(IV) oxidation. It can be also hypothesized that negative CCF of sulfate-ozone in winter are due to the local sulfate production in NYC driven by the use of high sulfur-content home heating oils, whereas there is limited $\mathrm{O}_{3}$ production.

CCFs for sulfate- $\mathrm{PM}_{2.5}$ and $\mathrm{OC}_{\mathrm{sec}}-\mathrm{PM}_{2.5}$ present moderate to strong (0.4-0.6) correlations over all lags. This result shows that sulfate and $\mathrm{OC}_{\mathrm{sec}}$ drive the $\mathrm{PM}_{2.5}$ mass concentrations, and also indicates that secondary particle formation requires more than $12 \mathrm{~h}$, i.e. such processes do not occur locally.

CCFs among SMPs and pollutants shared by the two sites are provided in Figures SI8 and SI9. Particles generally show significant positive correlations with $\mathrm{NO}, \mathrm{NO}_{2}, \mathrm{SO}_{2}$ and $\mathrm{PM}_{2.5}$ at lag 0 . However, correlations with $\mathrm{NO}, \mathrm{NO}_{2}$ and $\mathrm{SO}_{2}$ are higher for particles in the 50-100 nm range, while correlations with $\mathrm{PM}_{2.5}$ increase by increasing the particle size. This latter result is largely expected, since large particles mostly contribute to the $\mathrm{PM}_{2.5}$ mass.

\subsection{Identification of local sources}

CBPF plots are used to identify the potential local emission sources. The hourly air pollutant concentrations were matched with wind speed and direction values from the two weather stations. The criterion value was set at $>75$ th percentile. All data were used, e.g., no wind calm hours were removed. The results are provided in Figure 5 for QC and Figure SI10 for EP. For data collected at QC, CBPF were calculated separately for the cold and warm seasons split based on the seasonal time change (Figures SI11 and SI12).

Generally, CBPFs at QC and EP show similar profiles for most of the analyzed species. Such profiles remain constant through the cold and warm seasons. However, higher probabilities of concentrations $>75$ th percentile are found during the cold season for all of the locally emitted pollutants. In addition, there is less conversion of primary pollutants during winter due to reduced photochemical processes. High probabilities of $\mathrm{NO}, \mathrm{NO}_{2}, \mathrm{CO}, \mathrm{NMHCs} \mathrm{OC}_{\text {pri }}$, EC and SMP in the 30-100 $\mathrm{nm}$ range were attained during calm wind periods or under low/moderate wind speed $\left(<5 \mathrm{~m} \mathrm{~s}^{-1}\right)$ with no prevailing direction. This pattern is compatible with the dilution 
effect driven by winds and the consequent advection of fresh air masses, and is also explained by the inverse relationships of the daily cycles between wind speed and primary pollutants (Figure 4). The highest wind speeds were observed in the afternoon and were concurrent with minimal concentrations of the local-emitted species. These results further support attribution of $\mathrm{NO}, \mathrm{NO}_{2}$, $\mathrm{CO}, \mathrm{NMHCs}, \mathrm{OC}_{\text {pri }}$, EC and SMP in the 30-100 nm range to local emissions and/or fast atmospheric processes. However, it should be noted that the EC tracer method has limitations that may affect the $\mathrm{CBPF}$ analysis. It assumes a constant $\mathrm{OC} / \mathrm{EC}_{\text {pri }}$ ratio across different seasons, i.e. changes in temperature that may result in the extent of condensation of primary semivolatile OC. Thus, $\mathrm{OC}_{\mathrm{pri}}$ and $\mathrm{OC}_{\mathrm{sec}}$ may be biased and results should be used with caution.

$\mathrm{SO}_{2}$ shows increased probabilities with moderate westerly winds, i.e. toward the lower end of Manhattan. This direction is likely the result of emissions from central heating systems of the large buildings In NYC, the primary fuels used for space and water heating are fuel oils and natural gas. A large number of small residential and commercial buildings use distillate oil No. 2, while many larger buildings burn the less refined No. 6 (residual oil) with higher emission factors (US EPA, 2010; Kheirbek et al., 2014) or a mixture of Nos. 2 and 6 to produce No. 4 oil. In 2009-2010, No. 2 oil contained 0.2\% sulfur (by weight), while the content in Nos. 4 and 6 was higher $(0.3 \%)$. The annual building energy consumption by block area in NYC in 2009 reported by Howard et al., 2012 shows that Manhattan has very high energy consumptions with respect to other boroughs and it is therefore likely to emit higher amounts of $\mathrm{SO}_{2}$. However, shipping is another known strong source of $\mathrm{SO}_{2}$ (e.g., Isakson et al., 2001; Eyring et al., 2005) and the CBPF is compatible with emissions from the container port at the Port of Elizabeth, NJ.

Methane, $\mathrm{PM}_{2.5}$, sulfate, $\mathrm{OC}_{\mathrm{sec}}$ and particles $>100 \mathrm{~nm}$ exhibit high probabilities for moderate (4-7 $\mathrm{m} \mathrm{s}^{-1}$ ) winds blowing from SW. The highest probabilities are attained for air masses from Brooklyn. However, the relative high wind speeds associated with the CBPF indicate that the advection of air masses over Manhattan has the potential for raising their concentrations. However, it should be noted that results for $\mathrm{PM}_{2.5}$ in EP can be potentially biased due to the non-linear Julian Day based adjustment. This data handling is recognized to impair short-term fluctuations and peak concentrations (Schwab et al., 2006). Nevertheless, this known limitation, the good agreement between the CBPF results for $\mathrm{PM}_{2.5}$ in QC and EP and among $\mathrm{PM}_{2.5}$ and coarser particles in EP would indicate that the result at EP have been not excessively biased by the data correction. Despite sulfate and $\mathrm{OC}_{\mathrm{sec}}$ are related to secondary processes and, 
thus, may have a probable regional origin, it can be hypothesized that domestic heating and traffic may also contribute to their concentrations on a local scale.

Ozone show increased probabilities for strong $\left(>5 \mathrm{~m} \mathrm{~s}^{-1}\right)$ winds blowing from SSE. Thus, high ozone concentrations are observed when the winds blow from directions not heavily impacted by traffic, i.e. when $\mathrm{NO}$ is not sufficient to titrate out the $\mathrm{O}_{3}$.

CBPF for the smallest particles (20-30 nm) show a different pattern. At QC, the higher concentrations are for winds blowing from NW, while the probability for calm wind periods is very low $(<0.3)$. On the contrary, $\mathrm{CBPF}$ at EP shows a profile similar to other primary pollutants (moderate winds from $\mathrm{W}$ ). The pattern at QC is not found for any other species and indicates a source of ultrafine particles in the nucleation mode toward NW. Potential emissions from high density of urban areas and the presence of main roads (e.g., Long Island Expressway, Van Wyck and Whitestone Expressways, Grand Central Parkway) are compatible with this result. Highdensity urban areas and frequently congested main roads are widespread in Queens. For example, the Long Island Expressway generally experiences the highest traffic volumes in Queens County, in excess of 200,000 vehicles day ${ }^{-1}$ and it is frequently congested. As a consequence, minor roads in the area are also frequently congested. In addition, a large number of school buses moves in the area due to the College and other schools.

In addition to road traffic as a major source, the nucleation mode particles may be attributable to the emissions from LaGuardia Airport, approximately $5 \mathrm{~km} \mathrm{NW}$ of QC. Aircraft emit ultrafine particles in the nucleation range (Masiol and Harrison, 2014; Lobo et al., 2015), thus airports are known sources of UFPs. For example, Hudda et al. (2014) reported that emissions from the Los Angeles International Airport increase PNC 4-fold at $10 \mathrm{~km}$ downwind, while Keuken et al. (2015) reported that the particle number size distributions downwind of Schiphol Airport (The Netherlands) was dominated by ultrafine (10 to $20 \mathrm{~nm}$ ) particles. LaGuardia Airport is one of three commercial airports for NYC and had 379,000 plane movements in 2010 .

\subsection{Potential distant sources}

The potential locations of distant sources were evaluated through PSCF analyses. The hourly air pollutant concentrations were matched with the back trajectories. The criterion value was set to concentrations $>75$ th percentile. The PSCF surfaces were smoothed to decrease the 
noise due to the uncertainties of trajectories and to enhance the interpretability of maps. Results are shown in Figure 6 for QC and Figure SI13 for EP. For QC, the PSCF values were calculated separately for the cold and warm seasons (Figures SI14 and SI15).

Results show that continental eastern U.S. particularly the upper Ohio River Valley region was the highest probability source area for almost all the pollutants having likely regional origins, including $\mathrm{SO}_{2}, \mathrm{CH}_{4}, \mathrm{PM}_{2.5}$, sulfate, $\mathrm{OC}_{\text {sec }}$, and particles $>50 \mathrm{~nm}$. These patterns are almost constant during the cold and warm seasons. The probabilities for $\mathrm{NO}_{2}, \mathrm{SO}_{2}, \mathrm{CO}, \mathrm{NMHCs}$, $\mathrm{OC}_{\mathrm{pri}}, \mathrm{EC}$ and particles in the $50-100 \mathrm{~nm}$ range are generally less than 0.5. The maps do show probabilities $>0.5$ for methane, $\mathrm{PM}_{2.5}$, sulfate and particles $>100 \mathrm{~nm}$. The maps for both sites clearly show that the potential effects of regional transports rise with increasing particle dimensions, with the highest probabilities for particles in the $>200 \mathrm{~nm}$ range. However, the results for $\mathrm{OC}_{\mathrm{sec}}$ should be used with caution in the $\mathrm{CBPF}$ analysis given the limitations of the EC tracer method as discussed above.

PSCF maps for particles $>50 \mathrm{~nm}$ corresponded with the modeled emissions from the major UFP sources in the Eastern U.S. during summer as reported by Posner and Pandis (2015). The PSCF maps for particles in the 20-50 range do not show any pattern. The lack of any significant PSCF probability for finest particles means that they originate primarily from local sources and are not transported over long distances.

\section{CONCLUSIONS}

This study has provided direct information on the concentrations and trends of key air pollutants over high densely urbanized areas of NYC and Long Island. Primary and secondary OC are also estimated. Results enable some general considerations that can be summarized as follows:

- The seasonal, weekly and diurnal cycles of pollutants primarily emitted by anthropogenic sources (NO, $\mathrm{SO}_{2}, \mathrm{CO}, \mathrm{NMHCs}, \mathrm{OC}_{\mathrm{pri}}$, EC and 30-100 nm particles) are strongly shaped by emission factors, human habits, photochemical processes and weather. Typical sinusoidal seasonality with maxima during cold seasons and uni/bimodal daily cycles related to rush hours are found for most pollutants. Nitrogen dioxide also follows this behavior due to the fast oxidation of $\mathrm{NO}$ to $\mathrm{NO}_{2}$ driven by the atmospheric oxidants. Intra-species analysis by means of cross-correlations has also pointed out the strong relationships among primary air pollutants by showing high positive correlations at $0 \mathrm{~h}$ lag. Primary pollutants increase during 
wind calm periods or under slow wind regimes and the CBPF analysis has evidenced that they are emitted locally. In addition, no significant effects of regional transports of primary species are evidenced from PSCF analysis. Results indicate different potential local sources:

road traffic is the most probable source of nitrogen oxides, $\mathrm{CO}, \mathrm{NMHCs}, \mathrm{OC}_{\text {pri }}$, EC and 30$100 \mathrm{~nm}$ particles, while domestic heating burning fuel oils and shipping for $\mathrm{SO}_{2}$.

- $\mathrm{PM}_{2.5}$ and coarser particles are strongly related to secondary processes, as evidenced by the comparison with sulfate and estimated $\mathrm{OC}_{\mathrm{sec}}$. They show comparable seasonal and diurnal profiles, high correlations and relatively high lagged correlations over long periods $(+/-12$ h). Also, CBPF results show that the advection of regional air masses has a potential effect in raising their concentrations, while PSCF pointed out the Eastern continental U.S. as most probable remote source area.

- Both local and regional sources can be found for UFPs in the nucleation range (<30 nm). Results indicate that LaGuardia airport is a potential local source at Queens, while PSCF analysis does not reveal any dominant remote source area.

- Ozone is linked to the photochemical production and is delayed $(+2 \mathrm{~h})$ with respect the maxima solar radiation. Correlations and diurnal cycles point out on its potential high effect as oxidant for primary species. Despite the large set of ozone-precursor emitted by anthropogenic sources within NYC boundaries, CBPF analysis has revealed that most $\mathrm{O}_{3}$ is advected during high wind regimes, but not dominant source areas are evidenced by PSCF.

\section{ACKNOWLEDGEMENTS}

The authors gratefully acknowledge the NOAA Air Resources Laboratory (ARL) for the provision of the HYSPLIT transport and dispersion model and READY website (http://www.ready.noaa.gov) used in this publication and the National Renewable Energy Laboratory under the U.S. Department of Energy's Office of Energy Efficiency and Renewable Energy and its partners for the provision of solar radiation data. The work at Clarkson University was supported by the New York State Energy Research and Development Authority (NYSERDA) under agreement no. 59802. 


\section{REFERENCES}

Adam, M., Schikowski, T., Carsin, A. E., Cai, Y., Jacquemin, B., Sanchez, M., et al., 2015. Adult lung function and long-term air pollution exposure. ESCAPE: a multicentre cohort study and meta-analysis. European Respiratory Journal, 45, 38-50.

Anderson, J. O., Thundiyil, J. G., Stolbach, A., 2012. Clearing the air: a review of the effects of particulate matter air pollution on human health. Journal of Medical Toxicology 8, 166175.

Ashbaugh, L.L., Malm, W.C., Sadeh, W.Z., 1985. A residence time probability analysis of sulfur concentrations at ground Canyon National Park. Atmospheric Environment 19, 1263 1270.

Barnes, I., Hjorth, J. Mihalopoulos, N., 2006. Dimethyl sulfide and dimethyl sulfoxide and their oxidation in the atmosphere. Chemical Reviews 106, 940-975.

Bauer, J.J., Yu, X.Y., Cary, R., Laulainen, N. and Berkowitz, C., 2009. Characterization of the sunset semi-continuous carbon aerosol analyzer. Journal of the Air \& Waste Management Association 59, 826-833.

Benson, D.R., Yu, J.H., Markovich, A., Lee, S.-H., 2011. Ternary homogeneous nucleation of $\mathrm{H} 2 \mathrm{SO} 4, \mathrm{NH} 3$, and $\mathrm{H} 2 \mathrm{O}$ under conditions relevant to the lower troposphere. Atmospheric Chemistry and Physics 11, 4755-4766.

Brown, S. S., deGouw, J. A., Warneke, C., Ryerson, T. B., Dubé, W. P., Atlas, E., Weber, R. J., Peltier, R. E., Neuman, J. A., Roberts, J. M., Swanson, A., Flocke, F., McKeen, S. A., Brioude, J., Sommariva, R., Trainer, M., Fehsenfeld, F. C., Ravishankara, A. R.., 2009. Nocturnal isoprene oxidation over the Northeast United States in summer and its impact on reactive nitrogen partitioning and secondary organic aerosol. Atmospheric Chemistry and Physics 9, 3027-3042.

Buckley, S.M., Mitchell, M.J., 2011. Improvements in urban air quality: case studies from New York State, USA. Water, Air \& Soil Pollution 214, 93-106.

Cabada J.C., Pandis S.N., Subramanian R., Robinson A.L., Polidori A., Turpin B., 2004a. Estimating the secondary organic aerosol contribution to PM2.5 using the EC tracer method. Aerosol Science \& Technology 38,(S1), 140-155.

Cabada, J.C., Rees, S., Takahama, S., Khlystov, A., Pandis, S.N., Davidson, C.I. Robinson, A.L., 2004b. Mass size distributions and size resolved chemical composition of fine particulate matter at the Pittsburgh supersite. Atmospheric Environment 38, 3127-3141

Carlton, A.G., Wiedinmyer, C., Kroll, J.H., 2009. A review of Secondary Organic Aerosol (SOA) formation from isoprene. Atmospheric Chemistry and Physics, 9, 4987-5005.

Carslaw, D.C. K. Ropkins, 2012. openair — an R package for air quality data analysis. Environmental Modelling \& Software 27-28, 52-61.

Carslaw, D.C., Beevers, S.D., Ropkins, K., Bell, M.C., 2006. Detecting and quantifying aircraft and other on-airport contributions to ambient nitrogen oxides in the vicinity of a large international airport. Atmospheric Environment 40, 5424-5434.

Colette, A., Granier, C., Hodnebrog, Ø., Jakobs, H., Maurizi, A., Nyiri, A., Bessagnet, B., D'Angiola, A., D'Isidoro, M., Gauss, M., Meleux, F., Memmesheimer, M., Mieville, A., Rouïl, L., Russo, F., Solberg, S., Stordal, F., Tampieri, F., 2011. Air quality trends in Europe over the past decade: a first multi-model assessment. Atmospheric Chemistry and Physics 11, 11657-11678. 
Day, M.C., Zhang, M. Pandis, S.N., 2015. Evaluation of the ability of the EC tracer method to estimate secondary organic carbon. Atmospheric Environment 112, 317-325.

de Gouw, J.A., Brock, C.A., Atlas, E.L., Bates, T.S., Fehsenfeld, F.C., Goldan, P.D., Holloway, J.S., Kuster, W.C., Lerner, B.M., Matthew, B.M. Middlebrook, A.M., 2008. Sources of particulate matter in the northeastern United States in summer: 1. Direct emissions and secondary formation of organic matter in urban plumes. Journal of Geophysical Research: Atmospheres 113, D08301.

Donahue, N.M., Robinson, A.L. Pandis, S.N., 2009. Atmospheric organic particulate matter: From smoke to secondary organic aerosol. Atmospheric Environment 43, 94-106.

Duncan, B.N., Lamsal, L.N., Thompson, A.M., Yoshida, Y., Lu, Z., Streets, D.G., Hurwitz, M.M. Pickering, K.E., 2016. A space-based, high-resolution view of notable changes in urban NOx pollution around the world (2005-2014). Journal of Geophysical Research: Atmospheres 121, 976-996.

Eyring, V., Köhler, H.W., Van Aardenne, J. Lauer, A., 2005. Emissions from international shipping: 1. The last 50 years. Journal of Geophysical Research: Atmospheres 110(D17).

Felton D., 2005. Modifying $50^{\circ} \mathrm{C}$ TEOM Data to be more "FRM like" for AQI Reporting using a Non-linear Correction based on the Julian Day. 2005 AAAR Meeting, February 7-11, 2005, Atlanta, GA, USA.

Finlayson-Pitts, B.J., Pitts, J.N., 2000. Chemistry of the Upper and Lower Atmosphere: Theory, Experiments, and Applications. Academic Press, San Diego, p. 969.

Franklin, B. A., Brook, R., Pope, C. A., 2015. Air Pollution and Cardiovascular Disease. Current problems in Cardiology 40, 207-238.

Götschi, T., Heinrich, J., Sunyer, J., Künzli, N., 2008. Long-term effects of ambient air pollution on lung function: a review. Epidemiology 19, 690-701.

Hand, J. L., Schichtel, B. A., Malm, W. C., Pitchford, M. L., 2012a. Particulate sulfate ion concentration and SO 2 emission trends in the United States from the early 1990s through 2010. Atmospheric Chemistry and Physics 12, 10353-10365.

Hand, J.L., Schichtel, B.A., Pitchford, M., Malm, W.C. Frank, N.H., 2012b. Seasonal composition of remote and urban fine particulate matter in the United States. Journal of Geophysical Research 117, D05209.

Henze, D.K., Seinfeld, J.H., Ng, N.L., Kroll, J.H., Fu, T.M., Jacob, D.J. and Heald, C.L., 2008. Global modeling of secondary organic aerosol formation from aromatic hydrocarbons: high-vs. low-yield pathways. Atmospheric Chemistry and Physics 8,2405-2420.

Holmes, N.S., 2007. A review of particle formation events and growth in the atmosphere in the various environments and discussion of mechanistic implications. Atmospheric Environment 41, 2183-2201.

Hopke, P.K., 2016. Review of receptor modeling methods for source apportionment. Journal of the Air \& Waste Management Association, 66, 237-259.

Howard, B., Parshall, L., Thompson, J., Hammer, S., Dickinson, J. Modi, V., 2012. Spatial distribution of urban building energy consumption by end use. Energy and Buildings 45, 141-151.

Hudda, N, Gould, T., Hartin, K., Larson, T.V., Fruin, S.A., 2014. Emissions from an international airport increase particle number concentrations 4-fold at $10 \mathrm{~km}$ downwind. Environmental Science \& Technology 48, 6628-6635.

Huryn, S.M., Gough, W.A., 2014. Impact of urbanization on the ozone weekday/weekend effect in Southern Ontario, Canada, Urban Climate 8, 11-20. 
Isakson, J., Persson, T.A. Lindgren, E.S., 2001. Identification and assessment of ship emissions and their effects in the harbour of Göteborg, Sweden. Atmospheric Environment 35, 3659-3666.

Jenkin, M.E. and Hayman, G.D., 2000. Photochemical ozone creation potentials for oxygenated volatile organic compounds: sensitivity to variations in kinetic and mechanistic parameters. Atmospheric Environment 33, 1275-1293.

Kara, M., Hopke, P.K., Dumanoglu, Y., Altiok, H., Elbir, T., Odabasi, M., Bayram, A., 2015. Characterization of PM Using Multiple Site Data in a Heavily Industrialized Region of Turkey. Aerosol and Air Quality Research 15, 11-27.

Keuken, M.P., Moerman, M., Zandveld, P., Henzing, J.S., Hoek, G., 2015. Total and sizeresolved particle number and black carbon concentrations in urban areas near Schiphol airport (the Netherlands). Atmospheric Environment 104, 132-142.

Kheirbek, I., Haney, J., Douglas, S., Ito, K., Caputo Jr, S. Matte, T., 2014. The public health benefits of reducing fine particulate matter through conversion to cleaner heating fuels in New York City. Environmental Science \& Technology 48, 13573-13582.

Kim, E., Hopke, P.K., 2008. Source characterization of ambient fine particles at multiple sites in the Seattle area, Atmospheric Environment 42, 6047- 6056

Kim, E., Hopke, P.K., Edgerton, E.S., 2003. Source identification of Atlanta aerosol by positive matrix factorization, Journal of the Air \& Waste Management Association 53, 731-739.

Kley, D., Kleinmann, M., Sanderman, H., Krupa, S., 1999. Photochemical oxidants: state of the science. Environmental Pollution 100, 19-42.

Knibbs, L.D., Cole-Hunter, T. Morawska, L., 2011. A review of commuter exposure to ultrafine particles and its health effects. Atmospheric Environment 45, 2611-2622.

Kroll, J.H. and Seinfeld, J.H., 2008. Chemistry of secondary organic aerosol: Formation and evolution of low-volatility organics in the atmosphere. Atmospheric Environment 42, 3593-3624.

Lane T.N., Pandis S.N., 2007. Predicted Secondary Organic Aerosol Concentrations from the Oxidation of Isoprene in the Eastern United States. Environmental Science and Technology 41, 3984-3990

Lanzinger, S., Schneider, A., Breitner, S., Stafoggia, M., Erzen, I., Dostal, M., Pastorkova, A., Bastian, S., Cyrys, J., Zscheppang, A. Kolodnitska, T., 2016. Associations between ultrafine and fine particles and mortality in five central European cities-Results from the UFIREG study. Environment International 88, 44-52.

Laumbach, R. J., Kipen, H. M., 2012. Respiratory health effects of air pollution: update on biomass smoke and traffic pollution. Journal of Allergy and Clinical Immunology 129, 311.

Lee, J.H., Hopke, P.K., 2006. Apportioning sources of PM2.5 in St. Louis, MO using speciation trends network data. Atmospheric Environment 40, 360-377.

Liao, H., Henze, D.K., Seinfeld, J.H., Wu, S. and Mickley, L.J., 2007. Biogenic secondary organic aerosol over the United States: Comparison of climatological simulations with observations. Journal of Geophysical Research: Atmospheres 112, D06201

Lim, H.J., Turpin, B.J., 2002. Origins of primary and secondary organic aerosol in Atlanta: results of time-resolved measurements during the Atlanta supersite experiment. Environmental Science and Technology 36, 4489-4496. 
Lobo, P., Hagen, D. E., Whitefield, P. D., Raper, D., 2015. PM emissions measurements of inservice commercial aircraft engines during the Delta-Atlanta Hartsfield Study. Atmospheric Environment 104, 237-245.

Loomis, D., Grosse, Y., Lauby-Secretan, B., Ghissassi, F. E., Bouvard, V., Benbrahim-Tallaa, L. Guha, N., Baan, R., Mattock, H., Straif, K., 2013. The carcinogenicity of outdoor air pollution. The Lancet Oncology, 14, 1262-1263.

Masiol, M., Harrison, R.M., 2014. Aircraft engine exhaust emissions and other airport-related contributions to ambient air pollution: A review. Atmospheric Environment 95, 409-455.

Medved, A., Dorman, F., Kaufman, S.L., and Pöcher, A., 2000. A New Corona-based Charger for Aerosol Particles. Journal of Aerosol Science 31, 616-617.

Miller, S.M., Wofsy, S.C., Michalak, A.M., Kort, E.A., Andrews, A.E., Biraud, S.C., Dlugokencky, E.J., Eluszkiewicz, J., Fischer, M.L., Janssens-Maenhout, G. Miller, B.R., 2013. Anthropogenic emissions of methane in the United States. Proceedings of the National Academy of Sciences, 110, 20018-20022.

Ng, N.L., Kroll, J.H., Chan, A.W.H., Chhabra, P.S., Flagan, R.C. Seinfeld, J.H., 2007. Secondary organic aerosol formation from m-xylene, toluene, and benzene. Atmospheric Chemistry and Physics 7,3909-3922.

NY State Dep. Environmental Conservation, 2016. 2014 Region 2 Air Quality Data. Available at: http://www.dec.ny.gov/chemical/29310.html [last accessed: Jan 2016]

NYC Department of Health and Mental Hygiene, 2013a. New York City Trends in Air Pollution and its Health Consequences. New York City Department of Health and Mental Hygiene, New York, NY.

NYC Department of Health and Mental Hygiene, 2013b. Air Pollution and the Health of New Yorkers: The Impact of Fine Particles and Ozone. New York City Department of Health and Mental Hygiene, New York, NY.

NREL (National Renewable Energy Laboratory), 2012. National Solar Radiation Datadase 19912010 Update: User's manual. NREL Technical report NREL/TP-5500-54824.

Ostro, B., Hu, J., Goldberg, D., Reynolds, P., Hertz, A., Bernstein, L. Kleeman, M.J., 2015. Associations of Mortality with Long-Term Exposures to Fine and Ultrafine Particles, Species and Sources: Results from the California Teachers Study Cohort. Environmental Health Perspectives 123, 549-556.

Parrish D.D., Singh H.B., Molina L., Madronich S., 2011. Air quality progress in North American megacities: A review. Atmospheric Environment 45, 7015-7025.

Paulot, F., Jacob, D.J., Pinder, R.W., Bash, J.O., Travis, K. and Henze, D.K., 2014. Ammonia emissions in the United States, European Union, and China derived by high-resolution inversion of ammonium wet deposition data: Interpretation with a new agricultural emissions inventory (MASAGE_NH3). Journal of Geophysical Research: Atmospheres 119, 4343-4364.

Pekney, N. J., Davidson, C. I., Zhou, L., Hopke, P. K., 2006. Application of PSCF and CPF to PMF-Modeled Sources of PM2.5 in Pittsburgh. Aerosol Science \& Technology 40, 952961.

Pires, J. C. M. (2012), Ozone Weekend Effect Analysis in Three European Urban Areas. Clean Soil Air Water 40, 790-797.

Polidori, A., Turpin, B.J., Davidson, C.I., Rodenburg, L.A. Maimone, F., 2008. Organic PM2.5: Fractionation by polarity, FTIR spectroscopy, and OM/OC ratio for the Pittsburgh aerosol. Aerosol Science and Technology 42, 233-246. 
Polissar, A. V., P. K. Hopke, and J. M. Harris. 2001. Source Regions for Atmospheric Aerosol Measured at Barrow, Alaska. Environmental Science and Technology 35,: 4214-26.

Pope, C., Burnett, R. T., Turner, M. C., Cohen, A., Krewski, D., Jerrett, M., Gapstur, S.M., Thun, M. J., 2011. Lung cancer and cardiovascular disease mortality associated with ambient air pollution and cigarette smoke: shape of the exposure-response relationships. Environmental Health Perspectives 119, 1616-1621.

Posner, L.N., Pandis, S.N., 2015. Sources of ultrafine particles in the Eastern United States. Atmospheric Environment 111, 103-112.

Rattigan, O.V., Felton H.D., Bae M.S., Schwab J.J., Demerjian K.L., 2010. Multi-year hourly PM2.5 carbon measurements in New York: Diurnal, day of week and seasonal patterns. Atmospheric Environment 44, 2043-2053.

Rattigan, O.V., Civerolo K.L., Felton H.D., Schwab J.J., Demerjian K.L., 2016. Long Term Trends in New York: PM2.5 mass and Particle Components. Aerosol and Air Quality Research 16, 1191-1205

R Development Core Team, 2008. R: A language and environment for statistical computing. R Foundation for Statistical Computing, Vienna, Austria. ISBN 3-900051-07-0.

Rolph, G.D., 2016. Real-time Environmental Applications and Display sYstem (READY) Website (http://www.ready.noaa.gov). NOAA Air Resources Laboratory, College Park, MD.

Schwab, J.J., Felton, H.D., Rattigan, O.V., Demerjian, K.L., 2006. New York State urban and rural measurements of continuous PM2. 5 mass by FDMS, TEOM, and BAM. Journal of the Air \& Waste Management Association 56, 372-383.

Seinfeld, J.H., Pandis, S.N., 2006. Atmospheric Chemistry and Physics: From Air Pollution to Climate Change, second ed. John Wiley \& Sons, NewYork.

Shah, A. S., Langrish, J. P., Nair, H., McAllister, D. A., Hunter, A. L., Donaldson, K., Newby, D.E., Mills, N. L. 2013. Global association of air pollution and heart failure: a systematic review and meta-analysis. The Lancet 382, 1039-1048.

Smith, S.J., Aardenne, J.V., Klimont, Z., Andres, R.J., Volke, A., Delgado Arias, S., 2011. Anthropogenic sulfur dioxide emissions: 1850-2005. Atmospheric Chemistry and Physics 11, 1101-1116.

Stein, A.F., Draxler, R.R, Rolph, G.D., Stunder, B.J.B., Cohen, M.D., and Ngan, F., 2015. NOAA's HYSPLIT atmospheric transport and dispersion modeling system. Bulletin of the American Meteorological Society 96, 2059-2077.

Stockwell, W.R., 1994. The effect of gas-phase chemistry on aqueous-phase sulfur dioxide oxidation rates. Journal of Atmospheric Chemistry 19, 317-329.

Stockwell, W.R., Calvert, J.G., 1983. The mechanism of the HO-SO2 reaction. Atmospheric Environment 17, 2231-2235.

Stohl, A., 1998. Computation, accuracy and applications of trajectories- review and bibliography. Atmospheric Environment 32, 947-966.

Strader, R., Lurmann, F., Pandis, S.N., 1999. Evaluation of secondary organic aerosol formation in winter. Atmospheric Environment 33, 4849-4863.

Strak, M.M., Janssen, N.A., Godri, K.J., Gosens, I., Mudway, I.S., Cassee, F.R., Lebret, E., Kelly, F.J., Harrison, R.M., Brunekreef, B. and Steenhof, M., 2012. Respiratory health effects of airborne particulate matter: the role of particle size, composition, and oxidative potential-the RAPTES project. Environmental Health Perspectives 120, 1183-1189. 
Straif, K., Cohen, A. Samet, J., 2013. Air pollution and cancer. IARC scientific publication, 161, International Agency for Research on Cancer, 150 cours Albert Thomas, 69372 Lyon Cedex 08, France, 2013. Available from http://www.iarc.fr/en/publications/books/sp161/AirPollutionandCancer161.pdf.

Turner, M. C., Krewski, D., Pope III, C. A., Chen, Y., Gapstur, S. M., Thun, M. J., 2011. Longterm ambient fine particulate matter air pollution and lung cancer in a large cohort of never-smokers. American Journal of Respiratory and Critical Care Medicine 184, 13741381.

Turpin, B.J., Huntzicker, J.J., 1995. Identification of secondary organic aerosol episodes and quantification of primary and secondary organic aerosol concentrations during SCAQS. Atmospheric Environment 29, 3527-3544.

Uria-Tellaetxe, I., Carslaw, D.C., 2014. Conditional bivariate probability function for source identification. Environmental Modelling \& Software 59, 1-9.

US EPA, 2010. AP-42, 5th ed., Chapter 1: Regional Combustion Sources; U.S. Environmental Protection Agency, 2010; Vol. 1. Available at: http://www3.epa.gov/ttnchie1/ap42/ch01/final/c01s03.pdf [last accessed on February 2016]

US EPA, 2015. Inventory of U.S. Greenhouse Gas Emissions and Sinks: 1990 - 2013. US EPA document 430-R-15-004. US EPA, Washington DC, USA. Available at: http://www3.epa.gov/climatechange/Downloads/ghgemissions/US-GHG-Inventory-2015Main-Text.pdf [last accessed on January 2016]

Watson, J.G., Chow, J.C., Fujita, E.M., 2001. Review of volatile organic compounds source apportionment by chemical mass balance. Atmospheric Environment 35, 1567-1584.

Yu, S., Dennis, R.L., Bhave, P.V. Eder, B.K., 2004. Primary and secondary organic aerosols over the United States: estimates on the basis of observed organic carbon (OC) and elemental carbon (EC), and air quality modeled primary OC/EC ratios. Atmospheric Environment 38,5257-5268.

Yu, S., Bhave, P.V., Dennis, R.L. Mathur, R., 2007. Seasonal and regional variations of primary and secondary organic aerosols over the continental United States: Semi-empirical estimates and model evaluation. Environmental Science \& Technology, 41, 4690-4697.

Zhang, Q., Canagaratna, M.R., Jayne, J.T., Worsnop, D.R. Jimenez, J.L., 2005. Time-and size-resolved chemical composition of submicron particles in Pittsburgh: Implications for aerosol sources and processes. Journal of Geophysical Research: Atmospheres, 110, D07S09.

Zhang, R., Khalizov, A., Wang, L., Hu, M., Xu, W., 2011. Nucleation and growth of nanoparticles in the atmosphere. Chemical Reviews 112, 1957-2011. 


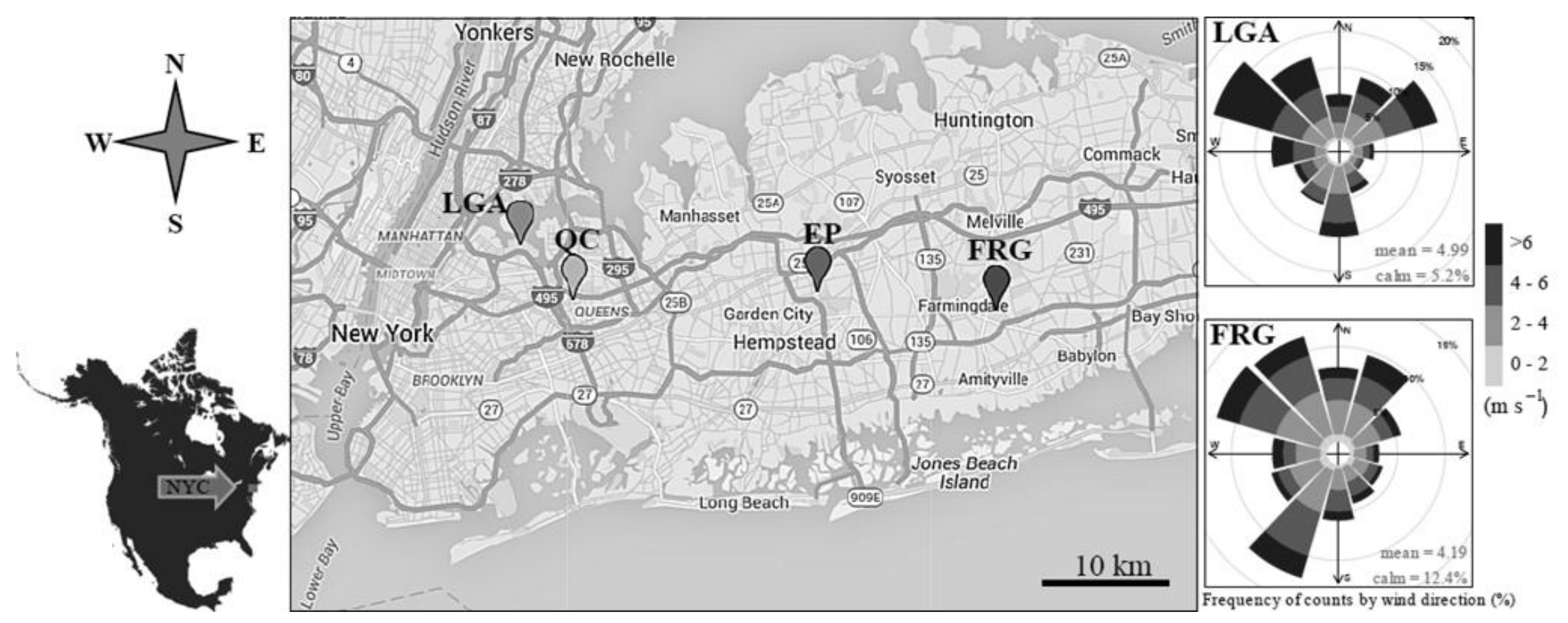

Figure 1. Map of the study area showing the two sampling sites ( $\mathrm{QC}=$ Queens College; $\mathrm{EP}=$ Eisenhower Park) and wind roses for the sampling period (July 2009-July 2010) at the two weather stations (LGA= LaGuardia Airport; FRG= Republic Airport). 


\section{$\square$ Eisenhower Park}
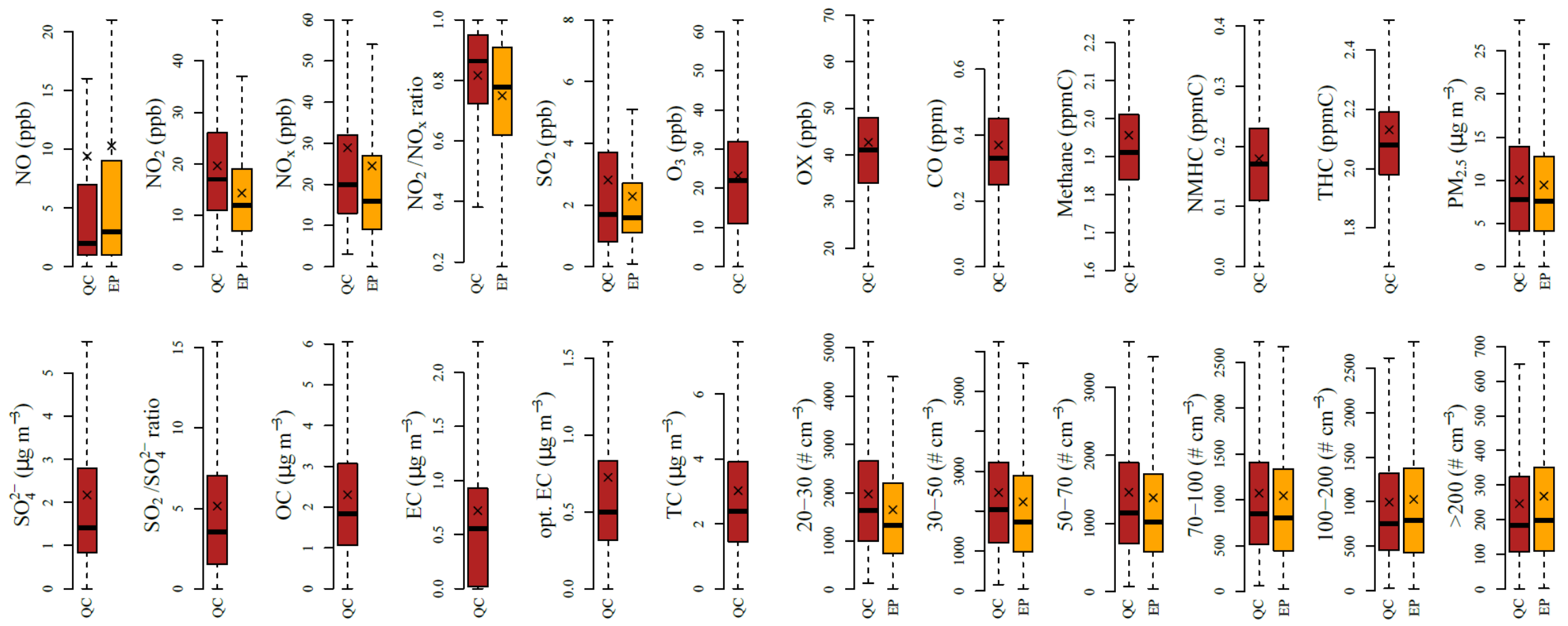

Figure 2. Boxplots of the analyzed pollutants. Lines $=$ medians, boxes $=25$ th- 75 th percentile ranges, whiskers $= \pm 1.5 *$ inter-quartile ranges, crosses $=$ arithmetic means. $\mathrm{OX}=$ total oxidants $\left(\mathrm{NO}_{2}+\mathrm{O}_{3}\right)$. 


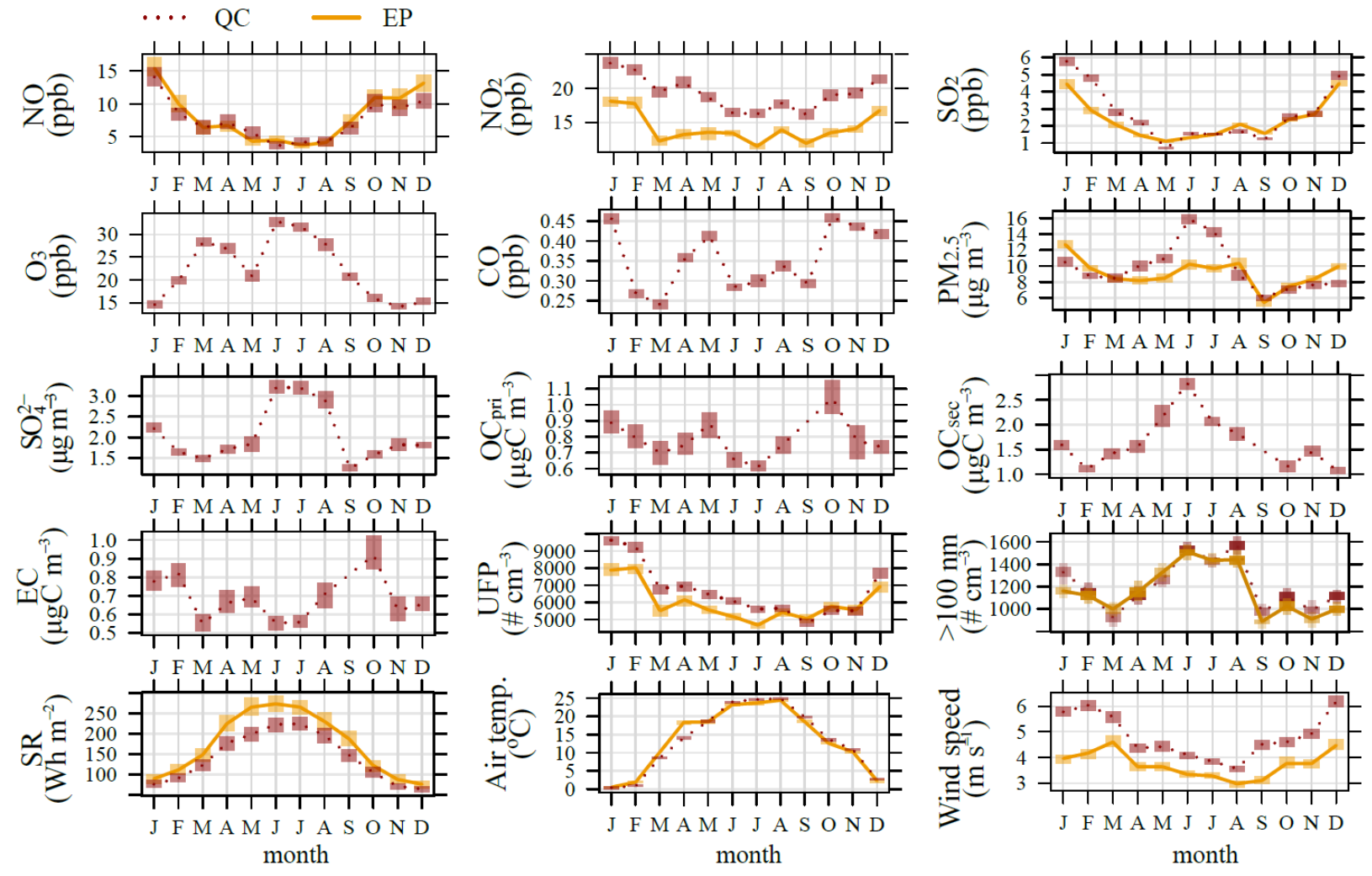

Figure 3. Seasonal variations of all monitored pollutants, derived parameters and some weather parameters. Each plot reports the monthly average concentrations as a filled line and the associated 95 th confidence interval calculated by bootstrapping the data $(n=200)$. 

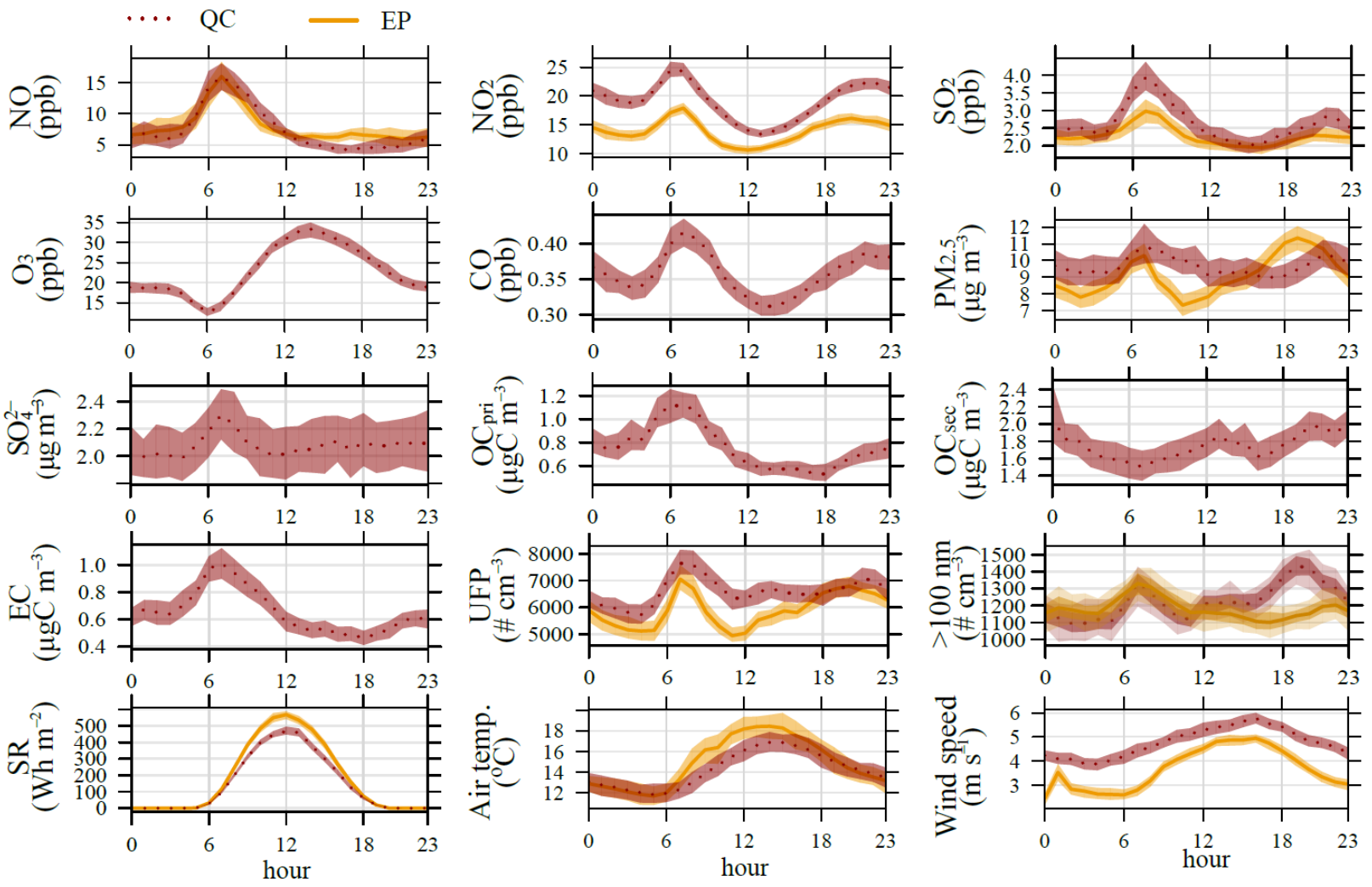

Figure 4. Diurnal variations in concentrations of measured pollutants. Each plot reports the average concentration as a filled line and the associated 95th confidence interval calculated by bootstrapping the data $(n=200)$. 

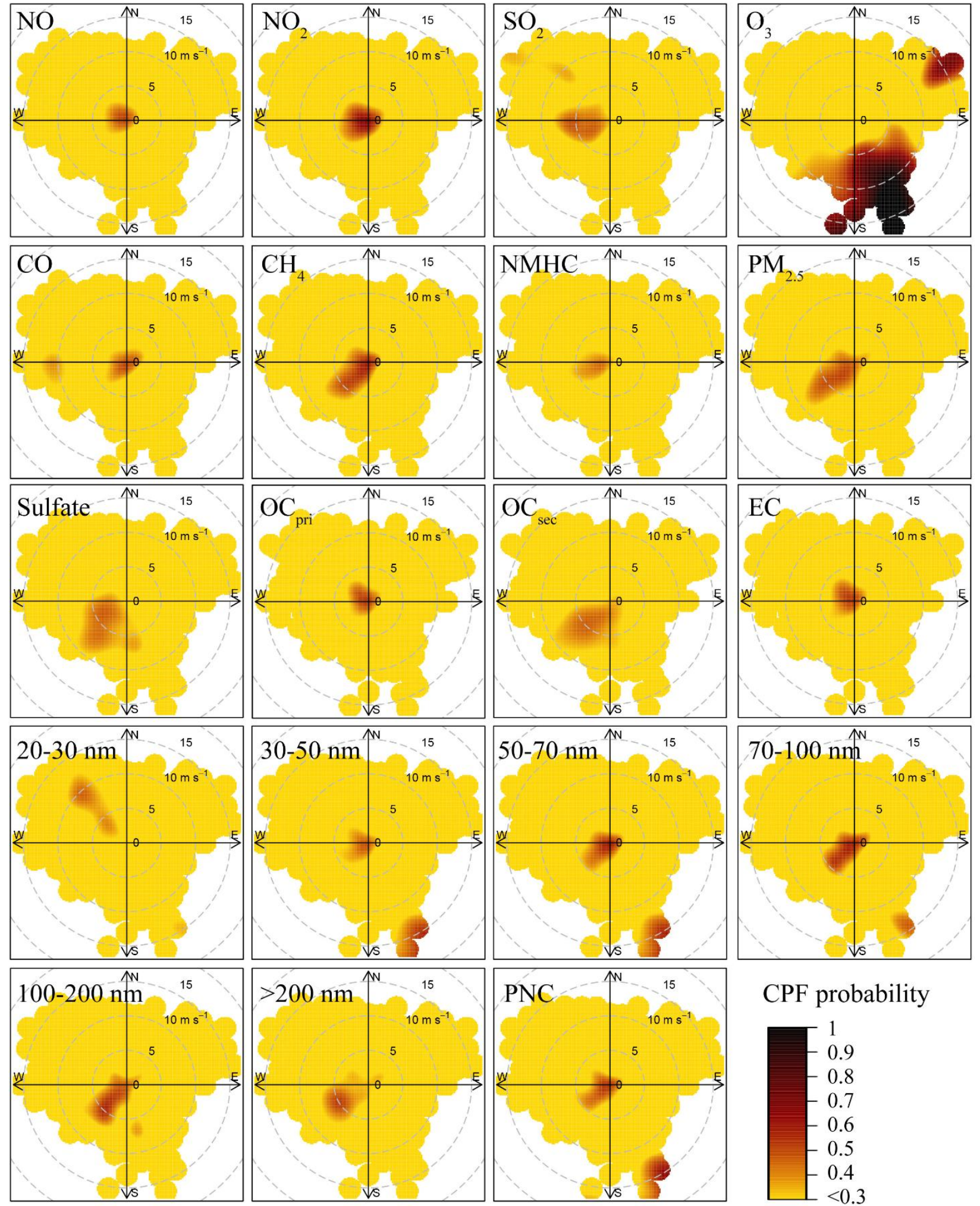

CPF probability

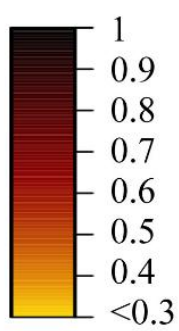

Figure 5. CBPF for pollutants measured at QC. CPF criteria: data from the whole sampling campaign; selected threshold: concentrations $>75$ th percentile. 


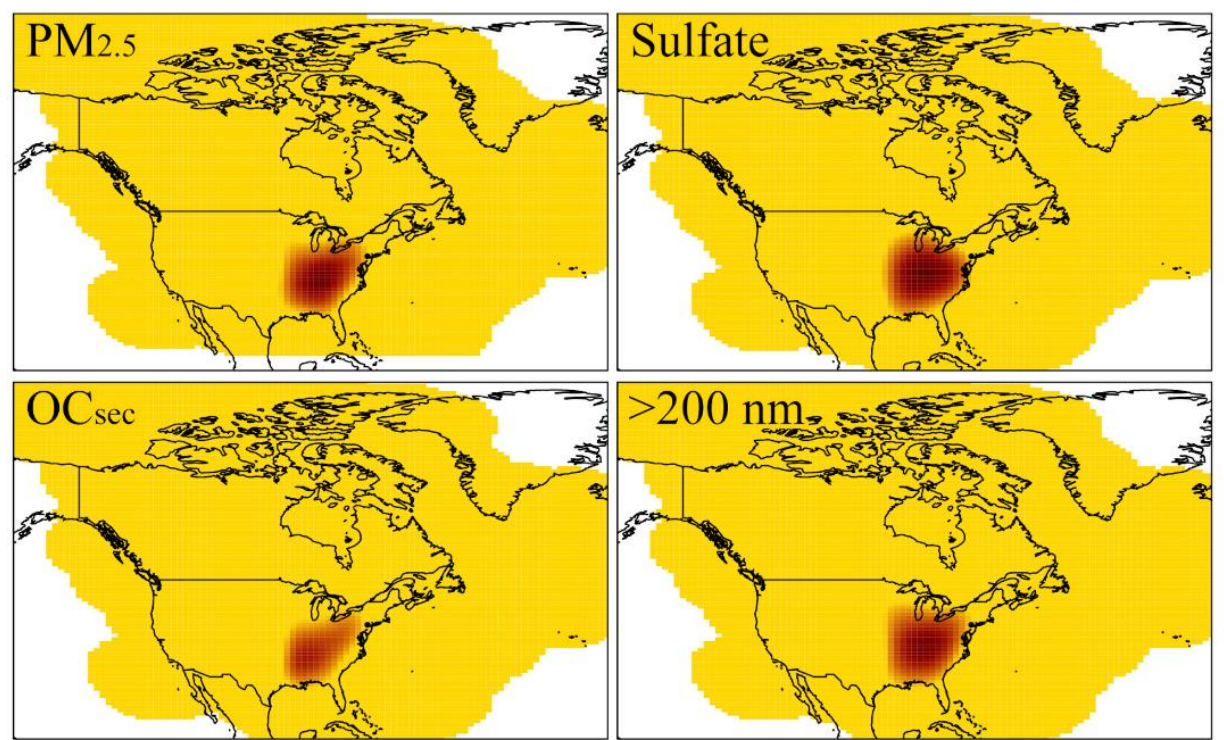

\section{PSCF probability}

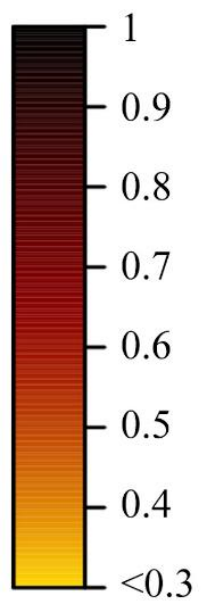

Figure 6. Smoothed PSCF maps for pollutants measured at QC during the whole sampling campaign. Selected threshold for PSCF: concentrations $>75$ th percentile. 